
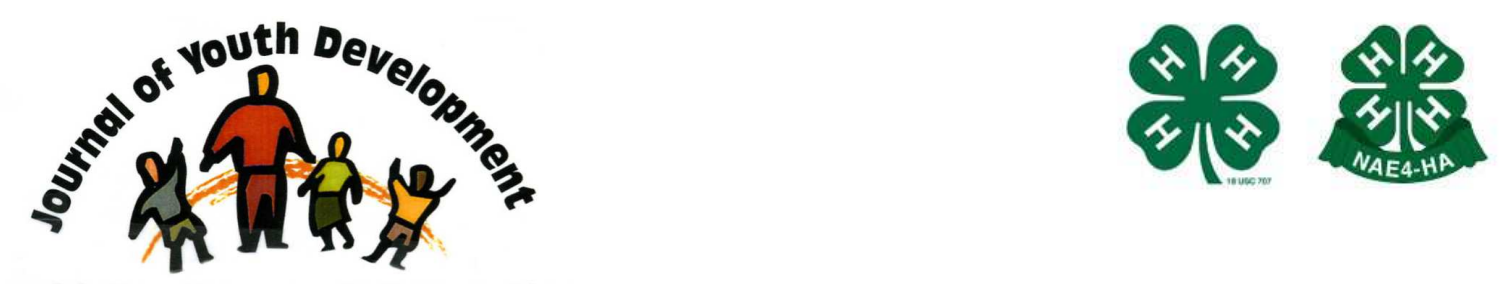

Bridging Research \& Practice

\title{
Youth Development and Extension Family and Consumer Sciences
}

\author{
Jan F. Scholl, PhD, CFCS \\ Associate Professor \\ 4-H Specialist, FCS Programs \\ The Pennsylvania State University \\ jscholl@psu.edu
}




\section{JOURNAL OF YOUTH DEVELOPMENT \\ bridging research and practice

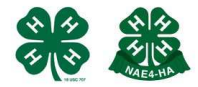

Volume 1, Number 2, September 2006

Article 0602RR001

\section{Youth Development and Extension \\ Family and Consumer Sciences}

Jan F. Scholl

The Pennsylvania State University

Abstract: Youth Development and Extension Family and Consumer Sciences is the theme of a special issue of the 2006 Journal of the National Extension Association of Family and Consumer Sciences. The 2006 issue includes seven peer-reviewed articles, research abstracts and resource bibliographies.

Topics are:

- conflict management for parents of teens,

- strengthening families through 4-H involvement,

- sexual abstinence for unmarried adolescents,

- youth entrepreneurship,

- effectiveness of EFNEP paraprofessionals,

- evaluation of a 4-H food camp and

- the history of the 4-H quilt block.

Abstracts of award winning research, scholarships and travel programs are also provided as are conference topics, resource bibliographies of family and consumer science-related articles in other refereed journals, and submission requirements for potential authors. The theme of the journal for 2007 is Extension Family and Consumer Sciences: Past and Present.

If you are not a member of NEAFCS, perhaps a co-worker will share their copy of this journal. NEAFCS publications subscription price is $\$ 10$ per year for non-members and in included in national membership dues. To order a copy of the 2006 youth development issue, send your $\$ 10$ fee to: NEAFCS, subscriptions, PO Box 849, Winchester, VA 22604-0849.

\section{References}

Scholl, J. (ed.) (2006). Journal of NEAFCS. Winchester, VA: National Association of Extension Family \& Consumer Sciences.

(C) Copyright of Journal of Youth Development $~$ Bridging Research and Practice. Content may not be copied or emailed to multiple sites or posted to a listserv without copyright holder's express written permission. Contact Editor at: patricia.dawson@oregonstate.edu for details. However, users may print, download or email articles for individual use.

ISSN 2325-4009 (Print); ISSN 2325-4017 (Online) 